\title{
The Rise of International Parliamentary Institutions: Purpose and Legitimation
}

\begin{abstract}
International parliamentary institutions (IPIs) have become an established feature of international politics. While scholars of international institutions have extensively studied why states delegate to international organizations (IOs) in general, they have said little about the creation of parliamentary bodies. Moreover, IPIs do not fit the functions commonly attributed to international delegation. By differentiating between general-purpose and taskspecific IOs, we hypothesize that general-purpose IOs establish and maintain parliamentary bodies that serve their legitimation needs. A nested quantitative and qualitative analysis based on an original dataset on the emergence of IPIs and case studies on the reform of the Economic Community of West African States and the development of the Pacific Islands Forum supports this explanation.
\end{abstract}

Keywords: international organizations, international parliamentary institutions, legitimation, authority, purpose JEL code F53

\section{Acknowledgements}

We gratefully acknowledge financial support from the Swiss National Science Foundation, NCCR "Challenges to Democracy in the $21^{\text {st }}$ Century". For comments on previous versions, we thank Jonas Tallberg and Michael Zürn as well as Arthur Benz, Daniel Bochsler, Tim Büthe, Daniele Caramani, Jeff Checkel, Robert Keohane, Tobias Lenz, Thomas Plümper, Stefaan Walgrave and three anonymous reviewers. We also thank the participants at workshops at WZB Berlin and Stockholm University, and audiences at the European Political Science Association, the Heidelberg conference of the Austrian, German and Swiss political science associations, the University of Munich and FU Berlin. We further wish to thank Liesbet Hooghe and Gary Marks for providing us with a prepublication version of their data on IO authority. Finally, we are very grateful to our research assistants: Jana Lipps, Kata Szabó, Siyana Timcheva, Marc Weber, Müge Özlütiras and Geraldine Alvarez. 
Why do international organizations (IOs) establish international parliamentary institutions (IPIs)? Scholars of international politics have long studied why states delegate competences to IOs in general, and to international bureaucracies and dispute settlement bodies in particular (Keohane 1984; Nielson and Tierney 2003). More recently, they have also focused on the inclusion of stakeholders and civil society in interstate policy-making (e.g., Tallberg et al. 2013). Parliamentary institutions, however, have received hardly any theoretical and empirical attention. ${ }^{1}$ Even though IPIs were a rare phenomenon before the 1990s, international politics has since experienced a gradual process of parliamentarization. In fact, a third of today's relevant IOs have IPIs (see FIGURE 1).

FIGURE 1 . The rise of international parliamentary institutions (IPIs)

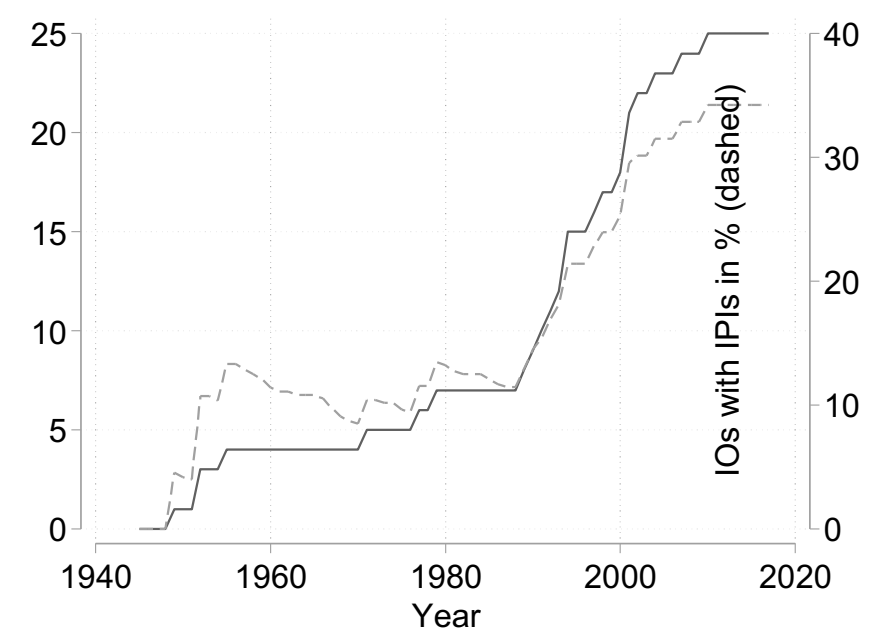

Note: Number of IPIs (solid line) and percentage of IOs with IPIs in all IOs 'with standing in international politics' (Hooghe and Marks 2015: 314) (dashed line). For further details, see the 'Data and variables' section.

IPIs are collegial transnational bodies composed of individuals who are either delegated by national parliaments from their ranks or - in rare cases - directly elected by citizens. They are similar to national parliaments in that they claim to represent citizens. The European Parliament (EP) of the European Union (EU) has directly elected members; examples without direct elections include the parliament of the Economic Community of West African States (ECOWAS) and the ASEAN Interparliamentary Assembly. IPIs thus provide a channel for member state representation that is different from intergovernmental bodies of IOs. Unlike the General Assembly of the

\footnotetext{
${ }^{1}$ For recent descriptive analyses, see, e.g., Cofelice (2012), Costa et al. (2013) and Kissling (2014). For an exceptional theory-oriented and comparative analysis, see Lenz (2013).
} 
United Nations, or the Council of the EU, their members are not members or delegates of national governments, but members of national parliaments or delegates of citizens. Unlike international bureaucracies, their members are not appointed by member state governments or recruited on the job market. Unlike international nongovernmental organizations (NGOs) with access to IOs, they are public bodies, not private organizations. And unlike intergovernmental bodies, international bureaucracies, and NGOs, the development and workings of IPIs are not that well understood.

There are several reasons for this lack of understanding. First, the rise of IPIs is more recent than the rise of IOs and other IO bodies. As Figure 1 shows, they have only become more numerous since the 1990s. Europe and Latin America pioneered IPIs, but Africa accounts for most of the growth after 1990. Second, their powers are circumscribed. The typical IPI receives information on the affairs of the IO and offers advice, but does not have any decision-making rights (see Figure A1 in the appendix). Only the EP and the Legislative Assembly of the East African Community share legislative decision-making rights with governments. The Central American Parliament and the parliament of MERCOSUR are entitled to receive responses to legislative suggestions. The remaining IPIs are purely consultative bodies with the right to information about decisions or no rights at all. Only 20 percent of IPIs have a voice in the appointment of key positions in the bureaucracy or decision-making bodies of the IO, and only the European Parliament and the Central American Parliament hold vetoes. Only six IPIs have to be consulted before member states change IO treaties. However, most IPIs are free to debate any topic, write their own rules of procedure, and decide on how to distribute their own budget.

Finally, the emergence of IPIs is difficult to reconcile with the most common functional explanations of why states create international institutions. IPIs do not provide superior policy expertise; they do not increase decision-making efficiency or quality; and they do not improve the implementation of IO policies by monitoring, sanctioning, or supporting state compliance. We thus arrive at the puzzle driving our research: why do member state governments increasingly decide to equip their IOs with IPIs - without, however, giving IPIs significant powers?

We suggest that IPIs perform other functions for IOs and member state governments than those commonly attributed to international bureaucracies and dispute-settlement bodies. Broadly speaking, IPIs are set up to help IOs and their member states legitimate the authority of IOs by analogy to national parliaments. (National) parliaments are the most prominent institutional manifestations of modern representative democracy. By representing the citizenship, deliberating the public good, authorizing general and binding laws, and monitoring the executive, they provide the state with democratic legitimacy. Correspondingly, governments see value in equipping IOs with parliamentary institutions for legitimation purposes. By mimicking a democratic institution 
from the domestic domain, giving citizen representatives access to the IO, letting them cultivate links between the IO and national parliaments and having them deliberate on the policies and development of the IO, governments seek to create the appearance of democratic legitimacy in response to demands and expectations of domestic actors and the international environment. At the same time, they seek to avoid being formally constrained by IPIs in global and regional governance. Governments want the democratic image of parliaments without the constraints that underpin this image at the national level.

Governments can hope to exploit the national parliament-IPI analogy most if there is a close institutional fit between the ideal-typical functions of parliaments and the apparent legitimation needs of an IO. We argue that IPIs are most relevant for general-purpose IOs. Task-specific IOs do not require the representative and deliberative functions of parliaments. In contrast, general-purpose IOs based on incomplete, open-ended contracts and community-building ambitions, need bodies such as IPIs that convey the impression of representing the people(s) of an international community and of deliberating democratically on public policy. Governments assume that this adds to the legitimacy of and supports the future development of the IO. Put differently, the weaknesses of parliaments in providing expertise, efficiency, and compliance render IPI creation a misguided legitimation strategy in task-specific compared to general-purpose IOs. By extension, we do not expect IPIs within preferential trade agreements (PTAs) unless PTAs are embedded in general-purpose IOs such as the EU, Mercosur or ECOWAS. PTAs are by definition task-specific; many are bilateral and do not have their own IO. Indeed, we do not find a single IPI attached to a PTA outside an IO.

We compare our expectation that general-purpose IOs are most likely to create IPIs with two theoretical alternatives. The first one assumes that an increase in IO authority generates demand for international parliamentarization, irrespective of the purpose of the IO, either because increased authority normatively requires more procedural legitimacy, or because governments have an interest in using IPIs to monitor powerful international bureaucracies. The second one conceives of IPI creation primarily as the international externalization of domestic procedural standards of IO member states. The elites and citizens of democratic states may wish to see IOs equipped with IPIs irrespective of the purpose that IOs pursue.

We examine these arguments in a nested quantitative and qualitative analysis. First, combining a novel dataset on the development of IPIs since 1950 with data on the authority of IOs (Hooghe et al. 2017), we conduct logistic regression analyses to identify whether IO purpose, member state democracy, and IO authority are conducive to the emergence and persistence of IPIs. Our analyses focus on international treaty reforms, in which the ensuing institutional instability generates plausible opportunities for IPI creation. The results are consistent with the expectation that IPI creation responds to the purpose rather than the authority of IOs. We also consider 
whether, instead of general purpose, IO membership size, policy scope, the global spread of democracy, the end of the Cold War, or a time trend account for IPI creation. Moreover, the effect of purpose is at least as important as that of domestic democracy. Indeed, the emergence of IPIs in democratic post-war Europe may mislead observers to attribute too much importance to domestic democracy, particularly in light of the recent spread of IPIs in African regional organizations.

To validate our statistical findings and probe into the mechanisms of IPI creation, we present two typical but diverse cases of IPI creation. In the case of ECOWAS, we find that the creation of an IPI followed an organizational reform, in which the general purpose of the IO was put into practice. The ECOWAS case further exemplifies IPI creation in a non-democratic context, in which domestic legitimation demand did not obtain. Instead, ECOWAS emulated the EU, which, at the time, was a model for legitimate regional integration. In contrast, the Pacific Islands Forum (PIF) did not establish an IPI even though the majority of its members are democracies. PIF was never a region-building organization with a general purpose. When PIF faced a legitimacy crisis in the early 2000s due to low policy performance, an IPI was never seriously taken into consideration.

\subsection{Explaining the Establishment of International Parliamentary Institutions}

Standard accounts of intergovernmental delegation to international agents do not provide a convincing rationale for the establishment of IPIs. In contrast, we argue that IPIs perform important legitimation functions for general-purpose IOs.

\subsection{International Parliamentary Institutions and Delegation}

According to the mainstream 'neoliberal' account, IOs are instruments of states. State executives establish and maintain international institutions in order to facilitate cooperation in areas of international interdependence and common interests. International regimes help overcome obstacles to effective cooperation by reducing transaction costs, providing expertise, defining and interpreting the rules of cooperation, monitoring state compliance, settling disputes among states, and sanctioning non-compliance (Keohane 1984). These tasks typically involve delegation to IOs. By delegating, states benefit from the expertise, impartiality, and efficiency of international agents and increase the credibility of their commitment to the international regime. International agents propose acceptable policies when states lack knowledge about the issues, about each other's preferences, or are caught in coordination problems and cooperation dilemmas. They perform monitoring tasks in a less costly and arbitrary way than state actors do, and offer impartial dispute resolution (Hawkins et al. 2006). From a 'compliance management' perspective, they also facilitate the implementation of international agreements by communicating with, and offering states technical expertise, as well as by strengthening their administrative 
capacity (Chayes and Handler Chayes 1998). Alternatively, in a fiduciary logic, international agents with a strong preference for the agreed policy are given the necessary autonomy to defend it against weakly committed governments (Majone 2001).

The problem with this account is that parliamentary institutions are not particularly good at providing these services (Lenz 2013). First, IPIs are not agents to which tasks can be delegated but additional principals. They represent the citizens of the member states alongside governments. Their political and policy preferences are prone to be misaligned with the preferences of IOs' intergovernmental bodies because IPIs often include opposition parties and change their composition as a result of national elections. Second, IPIs are not providers of independent or superior policy expertise. Parliaments represent the diversity of interests and values in society. Third, IPIs are a poor choice for alleviating problems of state commitment to IO policies and for monitoring and sanctioning state compliance. In principle, they are able to collect and disseminate information about non-compliance. Parliamentary scrutiny is, however, likely to be ineffective because IPI members may succumb to an adversarial partisan logic and have little reason to report national non-compliance. Independent and impartial monitoring is better served by technocratic or judicial bodies. Because IPI preferences may diverge from established IO policies as a result of electoral change and backlash, IPIs cannot serve as credibility-enhancing fiduciaries of governments either. In sum, IPIs defy common logics of delegation. Yet the exact IPI features that appear to be inefficient from a delegation perspective are important in governmental strategies for the legitimation of IOs.

\subsection{International Parliamentary Institutions and Legitimation}

States establish IOs primarily in order to manage and solve international problems. To the extent that IOs exercise authority in fulfilling these tasks, however, they generate higher support and elicit more compliance if they are perceived as legitimate by their participants and policy addressees (Franck 1988; Hurd 1999). Democracy is widely considered the 'gold standard' of legitimate authority (Buchanan and Keohane 2006: 416). In turn, parliaments epitomize democratic legitimacy. Parliaments are the core institutions of representative democracy the dominant form of democracy in the modern nation-state. Ideally, parliaments are elected by universal and equal suffrage, represent the range and strength of relevant political preferences in society, and provide a forum for deliberating the public good across a wide range of issues. These features justify the mandate of parliaments to make laws binding for the citizenship as a whole and to authorize redistributive and coercive policies. At the same time, parliaments have suffered strongly from the authority shift from states to IOs. IOs are formally dominated by state executives and offer venues of influence to interest groups and NGOs capable of organizing transnationally. By contrast, parliamentary representation has traditionally been rare and weak at the international level. The 'decline of parliament' is a major component of the standard account of the 'democratic deficit' of IOs 
(see Føllesdal and Hix 2006; Keohane et al. 2009). By creating IPIs, governments can therefore claim to boost the procedural, democratic legitimacy of their IOs (Tallberg and Zürn 2019).

The main mechanism through which IPIs are likely to contribute to the democratic legitimacy of IOs is mimicry. IPIs mimic national parliaments by convening citizen representatives, providing them with a forum to deliberate on the development and policies of the IO and to give advice and recommendations to the IO. According to the 'congruence model', which generally underpins the study of IO legitimacy, the correspondence of IO designs and procedures with socially accepted standards (such as national parliaments) generates organizational legitimacy (Lenz and Viola 2017). The related hypothesis of 'confidence extrapolation', according to which citizens translate confidence in national institutions to international organizations, has found support in a recent study on citizen confidence in the UN (Dellmuth and Tallberg 2015).

For the functional reasons outlined in the previous section, however, IO member governments are not intrinsically disposed in favor of international parliamentarization. Indeed, they found most IOs without IPIs. We assume therefore that member states react to demand for and expectations of legitimacy arising in their domestic political systems or in the international environment of the IO when they establish IPIs. At the same time, they keep the actual powers of IPIs to a minimum. They refrain from according IPIs the legislative competencies or the power to hold the IO's intergovernmental bodies or secretariats accountable that are the hallmark of democratic parliaments. In addition, they are skeptical towards direct elections to IPIs, lest the members of IPIs obtain too strong a popular mandate. In other words, when governments establish IPIs, they seek to legitimate IOs by creating the appearance of democracy without effective democratic empowerment. This legitimation strategy is known as ‘decoupling' in sociological institutionalism (Meyer and Rowan 1977).

We argue, however, that creating IPIs does not help governments to enhance legitimacy equally well across all IOs. The key to this argument is Liesbet Hooghe's and Gary Marks' (2003) distinction between two ideal-typical designs of multi-level governance: general-purpose organizations that are geared towards the governance of political communities within a territory but with an open-ended agenda of political issues, and taskspecific organizations that focus on the solution of specific problems for a variable and flexible membership. Because parliaments are general-purpose bodies, they have strong institutional affinity to general-purpose jurisdictions and organizations. Parliaments are the generally accepted model of democratic institutional legitimation for general-purpose governance within the state, where local and national governments bundle a broad range of issues confronting citizens in a territorially delimited community. Just as general-purpose organizations, parliaments represent polities, not policies. These two distinct organizational types can be found among IOs, too (Lenz et al. 2015). General-purpose IOs typically engage in international region-building on a continental or sub- 
continental scale based on open-ended policy and political mandates. By contrast, task-specific IOs typically focus on defined goals in a specific issue area, such as trade or defense, without the ambition of regional community building.

Establishing parliamentary bodies is a more convincing and, therefore, more promising legitimation strategy in general-purpose compared to task-specific IOs. Because general-purpose IOs are based on incomplete, open-ended contracts and engage in transnational community-building, they are both in demand of and more apt for the representative and deliberative procedures characteristic of parliamentary institutions (Tallberg and Zürn 2019). Parliaments and their generalist members focus on deliberating on the general rules, goals and development of an open-ended territorial community, rather than on executing narrowly-defined mandates (Hooghe and Marks 2015; 2016; Lenz et al. 2015). In addition, IPIs provide an institutional setting for fostering transnational communication and interaction.

To the extent that task-specific organizations are in demand for procedural legitimacy at all, they are better served by other legitimation practices such as issue-specific stakeholder representation or the involvement of experts. Critics of international parliamentarization point out that the political nature and lack of policy specialization of parliamentary bodies threatens to exacerbate legitimacy problems of task-specific organizations such as low performance or inefficient administration (Majone 2002). Because of poor institutional fit, governments interested in enhancing the legitimacy of task-specific IOs are unlikely to rely on IPIs, nor are critics of these organizations likely to demand parliamentary bodies. Consequently, we expect IPI creation to be correlated with the purpose of IOs.

(H1) The likelihood that an IO establishes and maintains an IPI is higher for general-purpose than for task-specific organizations.

We contrast our hypothesis with two alternative explanations. They share our basic assumption that IPIs are legitimation instruments but focus on different primary sources of demand for IO democratic legitimacy: accountability concerns and externalization of democratic procedures. First, demand for parliamentarization may not only occur in general-purpose organizations but also result from the delegation of authority to IOs in general. Through delegation, governments entrust international agents with making collectively binding decisions. Delegation to international bureaucracies moves policy-making further away from the citizens, lengthens the chain of accountability, weakens national parliaments, and comes with the risk of agency-shirking.

The more delegated authority IOs obtain, the more they generate concerns about accountability. Such concerns emerge in domestic as well as international contexts and come from a variety of actors: domestic actors 
of the member states such as political parties, advocacy groups, and national parliaments, or actors from the international environment of IOs such as other IOs, powerful alliance partners and donors, or transnational social movements and epistemic communities (Rittberger and Schroeder 2016). The stronger domestic and international legitimation demands become, the more member state governments are compelled to strengthen the legitimacy of IOs. In addition, member governments may seek to preempt legitimation pressure via enhanced transparency, participation, and accountability, as they expand the authority of IOs.

Aside from facing domestic and international demands for improving the democratic legitimacy of IOs, governments may be self-interested in creating IPIs as oversight mechanisms. Governments always experience a trade-off between the benefits of delegation and agency shirking. Even if IPIs do not provide benefits of delegation as such, they could be helpful in patrolling the agencies that do. One of the first IPIs, the Common Assembly of the European Coal and Steel Community, the predecessor of the EP, was given the right to hold accountable and censure the High Authority - which preceded the European Commission (Rittberger 2006). ${ }^{2}$ Thus, we hypothesize:

(H2) The likelihood that an IO establishes and maintains an IPI increases with the delegation of authority in the $I O$.

Second, we distinguish our explanation of IO parliamentarization from the expectation that IPIs result from the externalization of domestic democratic procedures to the international level. This account starts from member states' domestic political beliefs and norms rather than from IO authority. It is based on the externalization assumption of IR liberalism that political regimes seek to shape the international order in line with their own domestic orders and institutions. This argument can be extended to the design of international organizations. For instance, democratic membership is positively correlated with bureaucratic oversight and NGO access in IOs (Grigorescu 2010; Tallberg et al. 2016). Similarly, if the IO membership is composed of democratic countries, the norm of parliamentary representation and accountability is strong and uncontested. In such IOs, both the demand

\footnotetext{
${ }^{2}$ It could be argued that not only delegation but also pooling - the use of majority voting in IOs - encourages the creation of IPIs. However, empirical studies show that pooling is not independent of organizational purpose but, instead, predominantly a property of task-specific IOs. Indeed, it is seen as caused by organizational purpose. See Lenz et al. (2015). General-purpose IOs are more likely to deal with policies that have distributional implications and their open-ended, incomplete contracting may raise issues of national sovereignty and autonomy. Governments therefore want to keep their national veto. In addition, general-purpose IOs tend to have a smaller membership than task-specific IOs and are therefore less in need of pooling to overcome decision-making blockages. For these reasons, a correlation between IPI creation and pooling is likely, yet spurious: Member states of general-purpose IOs promote IPIs at the same time as they block or limit pooling. Our data features hardly any general-purpose IO that also engages in significant pooling, meaning that the real world of IOs does not afford the information necessary to disentangle the effects of pooling and organizational purpose.
} 
for and the acceptance of IPIs are presumably high. The elites and citizens of democratic states may wish to see IOs equipped with IPIs irrespective of the level and scope of authority they wield.

(H3) The likelihood that an IO establishes and maintains an IPI increases with the proportion of democracies in its membership.

\subsection{Quantitative Analysis}

\subsection{Data and variables}

Our analysis relies on a data set that measures the authority of 73 IOs with "standing in international politics" (Hooghe and Marks 2015: 314). When it comes to IOs, international relations scholars use a variety of data sets, which encompass a diverse number of entities. For instance, the two most used data sets, the Correlates of War IGO data set, and the Yearbook of International Organizations cover 496 and 7668 IOs, respectively. The large discrepancy between the number of IOs found in various data sets stems from how one defines an IO. Hooghe and Marks define IOs as organizations composed of three or more states, having a formal structure; a physical location or website; noteworthy permanent staff; a written treaty; and a decision-making organ that meets at least once a year (Hooghe et al. 2017: 15-17). Their definition therefore privileges functioning IOs. The universe of IOs is much larger than that, but Hooghe and Marks' starting point suits us because legitimation demands can only conceivably arise for IOs that reach a minimal level of international relevance and visibility. Including more IOs and controlling for their functionality - e.g., number of meetings - would have brought us to the same end-point. We combine the Hooghe and Marks sample of IOs with our own original data that maps the formation and the characteristics of IPIs. For each of the 73 IOs, we are thus able to see whether and when they established IPIs.

The dependent variable we use in the analysis is the existence of an IPI in an IO in a time period ranging from 1945 to 2010. Consequently, we continue to observe IOs even if they have already created an IPI at an earlier point in time. This approach informs us about the conditions under which IPIs emerge and persist in IOs. It therefore assumes that the dismantling of parliamentary bodies is possible and would indeed occur should the structural incentives of governmental decision-makers change. In practice, IPIs have never been dismantled, although a reform proposal in 2013 threatened to eliminate the parliament of the Andean Community. We consider alternative operationalization choices below.

We only observe IOs at the moment of treaty reform, and not on a yearly basis. Yearly data would artificially exaggerate our number of observations and suggest an unwarranted level of certainty around our 
findings. It is not plausible for an IO that has existed for five decades, to have had 50 genuine opportunities to create an IPI. Many years in an IO's existence are characterized by institutional stability and routine policymaking. Instead, we identify moments of institutional instability by isolating all formal treaty changes that the IOs in our study have undertaken. Accordingly, we conceptualize each treaty change as an institutional reform opportunity — and, therefore, a window to create or dissolve a parliamentary body. ${ }^{3}$ Based on this setup, taking into account a limited amount of missing information on the explanatory variables, the analysis relies on 217 observations drawn from 70 IOs.

Our main variable of interest is the organizational purpose of IOs. Our theoretical argument distinguishes general-purpose and task-specific organizations. We consider an IO to be general-purpose whenever its treaty contains open-ended contractual clauses. These clauses often include an open-ended list of objectives and engage in calls to region-building. The treaty of a task-specific IO is problem-driven, leaves no room for interpretation over its objectives and does not express region-building ambition. IO purpose rarely changes. Only six initially task-specific IOs changed to general-purpose. The appendix shows our classification of all IOs as task-specific or general-purpose. In line with our argument, out of the 25 IPIs in our sample of IOs, only 3 belong to task-specific IOs, while only 9 out of our 31 general-purpose IOs do not have a parliamentary institution.

The two main alternative explanations refer to delegated IO authority and member state democracy (the appendix contains further details on the operationalization). In order to measure delegation, we rely on data by Hooghe et al. (2017) who provide a time-varying index of the executive competences, agenda rights, and decisionmaking capabilities of IO secretariats. We operationalize the democratic membership of IOs as the share of member states with a Polity IV score above 6, the conventional democracy threshold in the Polity IV dataset.

In the robustness tests, we consider additional control variables. Governments might create IPIs to facilitate coordination across many member states or policies. IO policy scope and the size of IO membership could correlate with IO purpose. We measure membership size in terms of the number of member states. For the measurement of policy scope, we classified an organization to have narrow scope if its competences were confined within a single policy field, and wide scope if competences cut across fields. Finally, we will explore various time trends such as whether IPI creation correlates with the time-varying global average state of democracy, the distinction between pre- and post-Cold War, or a yearly trend. The appendix includes summary statistics.

\footnotetext{
${ }^{3}$ We acknowledge the possible objection that governments might initiate treaty reforms with the express purpose of creating a parliamentary body. By selecting observations based on treaty reform, we might thus overstate the probability of IPI creation. Empirically, however, only about a third of the cases in our analysis feature the creation of a new IPI or maintenance of a pre-existing one.
} 


\subsection{Empirical Results}

We examine IPI creation using logistic regression analysis on an IO-treaty reform data set. Due to the limited variation in the creation of IPIs in the world of internationally relevant IOs, our models necessarily remain at the level of a systematic, multivariate description of IO characteristics conducive to the existence of parliamentary bodies. The evidence thus obtained may be judged in terms of consistency with our causal hypotheses. We can compare the consistency of the evidence with our argument and alternative explanations focusing on delegation and democracy. However, the analysis itself does not establish (i.e., independent of our interpretation) whether the relationships we find are causal-for example, in the sense that unobserved confounding factors can be ruled out as in an experimental design. To further strengthen the empirical basis of our causal claims, we will add process level evidence in the subsequent section.

TABLE 1. Logistic regression models of the presence of parliamentary bodies (IPIs) in IOs

\begin{tabular}{llll}
\hline & $\boldsymbol{\beta}$ & $\mathbf{S E}$ & $\mathbf{p}$ \\
\hline Purpose & 3.11 & 1.32 & 0.01 \\
Delegation & 2.25 & 3.03 & 0.45 \\
Democracy & 3.03 & 1.55 & 0.05 \\
Year & 0.04 & 0.02 & 0.09 \\
Constant & -7.56 & 2.20 & 0.00 \\
\hline $\mathrm{N}$ & 217 & & \\
IOs & 70 & & \\
LL & -63.82 & & \\
\hline
\end{tabular}

Note: The unit of analysis is the IO-treaty reform pair. Standard errors, clustered by IO, were generated through 2000 bootstrap replications. LL: (Pseudo) log likelihood.

TABLE 1 presents our main logistic regression model pertaining to the existence of IPIs in IOs. It includes our main independent variable (Purpose) as well as two variables capturing the main alternative hypotheses (Delegation and Democracy) and a control for a yearly time trend. The standard errors are generated through bootstrapping, clustered by IOs. This is appropriate given that we do not analyze a well-defined sample of a population. In line with our theoretical expectation in H1, we find a positive and statistically significant relationship between the purpose of an IO and IPI existence. We also observe a plausible, positive and significant effect of the democratic membership of an IO. We do not find a significant relationship between IPI existence and delegation. 
FIGURE 2. Predicted probabilities of IPI existence in IOs

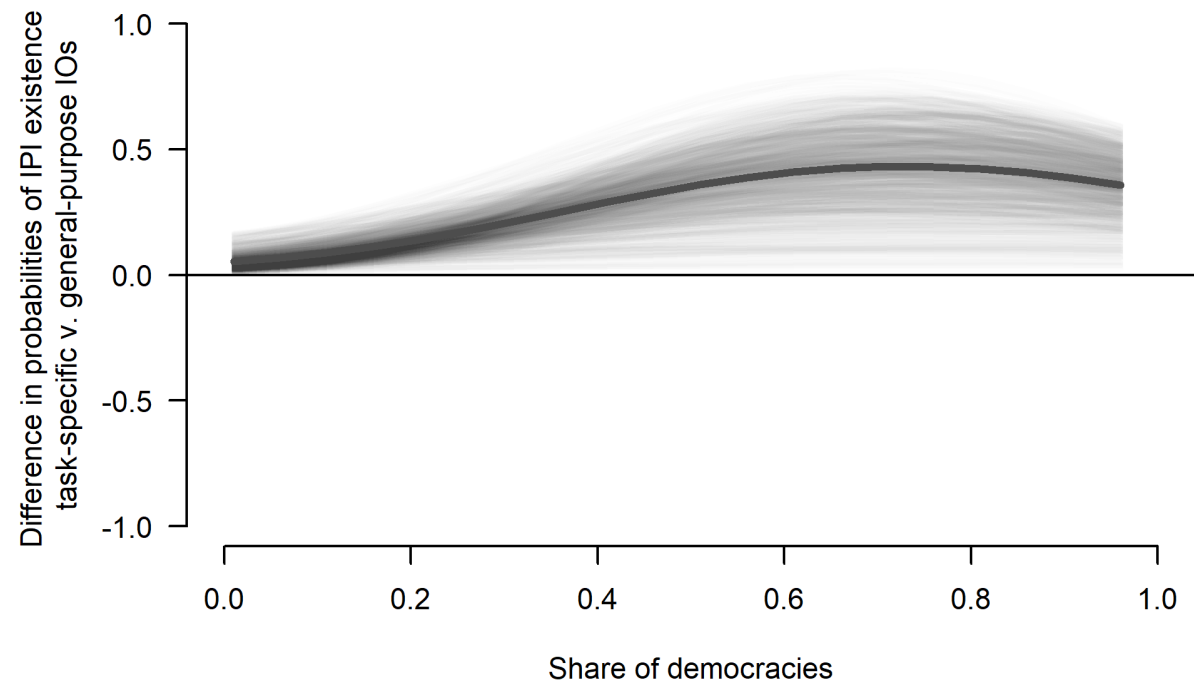

Note: Predicted probabilities based on 1,000 random draws from the parameter distribution of the model in TABLE 1 (for further details, see footnote 4).

FIGURE 2 illustrates how the difference between task-specific and general-purpose organizations affects the predicted probability that an IO has an IPI. ${ }^{4}$ In a logit model, this predicted probability also depends on the values of other variables in the model. Instead of focusing only on one particular state of domestic democracy (such as the mean or median), we display the contrast between task-specific and general-purpose organizations across all observed levels of democracy. ${ }^{5}$ Across all levels of member state democracy, general-purpose organizations are far more likely to feature IPIs than their task-specific counterparts. The difference in predicted probabilities is consistently substantial, on average (black line) and across the draws from our parameter distribution (grey lines).

\subsection{Robustness checks}

We explore these results in several robustness checks, which we summarize here (full results are included in the appendix). Primarily, one might be concerned that our analysis does not sufficiently account for time

\footnotetext{
${ }^{4}$ The predicted probabilities are estimated based on 1,000 random draws from the estimated parameter distribution of the Model in TABLE 1. For each draw, we estimate the average predicted probabilities across the observations in our data for different values of our variables of interest. In FIGURE 2, we show variability of the difference in predicted probabilities between task-specific and general-purpose IOs across the 1,000 simulations, discarding the top and bottom 2.5 percent (this can be interpreted as a 95 percent confidence interval).

${ }^{5}$ It is worth noting that FIGURE 2 does not show an interaction effect. That the difference between task-specific and general-purpose organizations widens over levels of democracy has to do with the non-linear transformation of the predictions of the logit model (i.e., log odds) into probabilities (see Berry et al. 2010).
} 
dependencies in the data or fail to exploit the insights to be gained from studying variation within IOs. Unfortunately, there is too little variation in the data (in the creation of IPIs as well as in the key explanatory variable, IO purpose) to analyze variation within IOs directly (e.g., by adding fixed IO effects to our model). This is why we explore case evidence below. Two additional analyses add to our confidence in the results. First, we explored the relationship of IO purpose and IPI creation in a propensity score matching analysis. ${ }^{6}$ We estimated propensity scores by regressing IO purpose on the alternative explanations, delegation and democracy, as well as control variables (the global democracy average, number of member states, and year). We find that the probability of IPI creation in general-purpose IOs is 27 (95\%-CI: 15-39) percentage points higher than in task-specific IOs. Second, we conducted a survival analysis tracing IOs from the moment of their foundation to the creation, if any, of an IPI. This analysis implies that the rate of IPI creation in general-purpose IOs is about 1.5 to 2 times greater than in task-specific organizations. Analyzing the data with the IO-year instead of the IO-treaty reform as the unit of analysis reproduces the relationship between IO purpose and IPIs as well.

We also explore the stability of the results of our main model by adding further control variables (a detailed discussion and regression diagnostic tests are included in the appendix). First, in a model that additionally controls for the worldwide average democracy level and the number of IO member states, the relationship between IO purpose and IPI creation becomes considerably more uncertain $(\mathrm{p}=.13)$. However, in terms of magnitude the relationship remains the strongest in the model. Second, we explored whether IPI creation in fact depends on the policy scope rather than the general purpose of IOs. Indeed, as Lenz and colleagues (2015) observe, generalpurpose IOs tend to have a broad policy scope although, as our case studies show, these two attributes do not have to go together and have different meanings for policy-makers. Because scope and purpose correlate highly $(\mathrm{r}=.8)$, they cannot be included in the same model. Instead, we re-estimated our main model replacing purpose with scope and compared model fit based on the Akaike and Bayesian information criteria. A model including purpose is clearly preferable to one including scope. Third, in light of criticism of the use of polity to measure democracy, we alternatively operationalized IO democracy based on the Varieties of Democracy dataset (Coppedge et al. 2016). This renders the relationship between IO democracy and IPI creation insignificant, while not affecting the findings regarding IO purpose. Finally, we distinguished the pre-and post-1990 periods and also excluded outliers such as the European Union, albeit without impact on the results.

The reader might also point out that, once created, IPIs will develop institutional inertia and persist regardless of changing circumstances. In other words, factors beyond the scope of our theoretical argument arise,

\footnotetext{
${ }^{6}$ Alternatively, nearest neighbor matching yields very similar results.
} 
rendering observations after the initial creation of IPIs irrelevant for the evaluation of our expectations. In view of this concern, we estimated the same logit model shown here including observations only until IPI creation (see Table A3 in the supplementary appendix). The results from this analysis underline the important link between IO purpose and IPIs.

In sum, the empirical results are consistent with the theoretical expectation that IPIs arise and persist in general-purpose IOs. We also find that democratic IOs are more likely to create IPIs although this result depends on the operationalization of democracy with polity IV data. We find no support for the alternative explanation linking the existence of parliamentary bodies to the delegation of authority to IO secretariats. As highlighted, the limited amount of variation in the creation of IPIs among contemporary IOs implies that the models presented here have to remain at the level of describing associations that, as discussed, are consistent with our causal claims but do not show causality empirically. Given these limitations, and to add further evidence on the causal mechanisms envisaged in our argument, we turn to a qualitative examination of the process-level implications of our arguments.

\subsection{Case Studies}

In order to further investigate our causal claims about the process of IPI creation, we conduct two processtracing case studies in a nested design (Lieberman 2005). In a nested analysis, the selection and study of specific cases are guided by the results of a previous large-n analysis, which offered information about the position of cases and the cross-case relationships in the larger population. Because our large-n analysis suggests a relationship between IO type (general-purpose or task-specific) and IPI existence, we design the case studies to test this finding further, while also ruling out the potentially confounding effect of democratic membership. In addition, the case studies give us the opportunity to explore the causal mechanism of IPI establishment further.

We employ two diverse but typical cases. Typical cases are "typical examples of some cross-case relationship" or "on-the-line" cases; diverse cases "illuminate the full range of variation" in the relationship (Seawright and Gerring 2008: 297). In our study, diverse typical cases are general-purpose IOs with an IPI, on the one hand, and task-specific IOs without an IPI, on the other. In addition, we increase analytical leverage in selecting typical cases that qualify as least-likely cases in light of the alternative, democracy-focused explanation. Specifically, we aim for contrasting a general-purpose IO with an autocratic membership at the time of IPI creation and a task-specific IO with a democratic membership. Our alternative hypothesis would predict that autocratic membership inhibits IPI creation even in the case of a general-purpose IO and that democratic membership should facilitate IPI creation even in a task-specific IO. 
Based on these considerations, we choose ECOWAS as a positive typical case (with a non-democratic membership) and PIF as a negative typical case (with a democratic membership). PIF is an IO that oversees policies in various domains, yet the organization is not a general-purpose one given that member states never agreed to region-building. In concurrence with our argument, PIF never established an IPI, even though its members are largely democratic. ECOWAS was established in 1975 as a general-purpose IO and created its parliament in 1993, when an institutional reform reinforced its region-building ambitions. ECOWAS member states were not democracies at the time of IPI creation, even though democratization processes were underway in some of them.

The causal mechanism - IPI creation as a legitimation strategy for general-purpose IOs - that we examine in these two cases runs from the type of IO to the creation of an IPI. We are interested in identifying the conditions under which proposals for IPI creation are made, the actors that propose and oppose IPI creation and the arguments they put forward to justify their claims. We expect to observe that the establishment or major institutional changes of general-purpose IOs trigger concerns about the legitimacy of the IO and generate demands for democratic representation and procedures at the IO level. We further assume that proponents and opponents of IPI creation link their stances to the purpose and the legitimacy of the IO.

\subsection{The establishment of the ECOWAS Parliament}

Regionalization in West Africa started relatively quickly, only a few years after the wave of decolonization of the early 1960s. After a series of setbacks, the ECOWAS was founded in 1975 with 15 West African countries. This case study focuses on the process of reform of the ECOWAS treaty in 1993 that created the ECOWAS parliament. Specifically, we describe the conditions under which the member states negotiated the treaty reform and the objectives they held. We find that the motivation to set up an IPI came from ECOWAS' renewed engagement with region-building goals during the revision of its institutional architecture, set off by a de facto expansion of its policy scope. Contrary to the democracy hypothesis, the IPI was not established due to member states' attachment to democratic norms, as few ECOWAS members were democracies at the time.

ECOWAS started out as an economic project at the behest of Nigeria. The 1975 institutional setup of ECOWAS reflected both Nigeria's attempt at regional supremacy as well as the African members' newcomer status on the international stage (Bach 1983; Ojo 1980). In particular, while most African states feared becoming dependent or subservient to post-colonial foreign powers and their multinational corporations, several West African countries remained under France's sphere of influence (Ojo 1980). ECOWAS was one of Africa's integration pioneers. The general-purpose treaty was engendered by pan-Africanism, with the objective of promoting cooperation in "all fields of economic activity", and included a clearly open-ended list of objectives, referring to "activities calculated to further the aims of the Community as the Member States may from time to 
time undertake in common" (ECOWAS 1975). Initially, member states saw no need for an international parliament and indeed, there seems to have been no discussion on this subject around the signing of the original ECOWAS treaty.

Initially, the general-purpose nature of the IO, clearly established by the communitarian focused wording of the treaty preamble and the open-endedness of its objectives did not materialize into region-building initiatives. Rather, the IO focused only on economic integration. During the first decade of existence, this gradually expanded to include cooperation and coordination in an increasing number of economic areas, and eventually a common market (Ojo 1980). However, the failure to implement decisions and meet financial obligations, together with animosity between members (ECOWAS 1991a) and increasing political turmoil in Liberia, awakened the African states to the need for a more robust institutional format (Dennis and Brown 2004; Mair and Peters-Berries 2001).

A major turning point occurred after the end of the Cold War, when West Africa saw a proliferation of violent intra-state conflicts. This incited innovation in the regional context. "Peace, security and conflict management" (Dapaah-Agyemang 2003) became the main drivers of institutional transformation. The best example is the formation of a Nigerian-led military alliance with UN mandate under the name of ECOWAS Ceasefire Monitoring Group (ECOMOG) in 1990. The alliance had a multinational peacekeeping, peacemaking and peace-enforcement role and therefore de facto expanded the ECOWAS' scope to include security (DapaahAgyemang 2003; van Nieuwkerk 2012; also see Marc and Verjee 2015). ${ }^{7}$ That same year, in 1990, the Authority of Heads of State and Government issued a directive calling for the appointment of a "Committee of Eminent Persons for the review of the ECOWAS treaty," effectively starting the process of reform (ECOWAS 1992). Two years later the Committee produced a report that emphasized "promoting and sustaining internal peace, stability and security in Member States for the continued survival and success of ECOWAS" (Eminent Persons Report 1993). Following the recommendations of the Eminent Persons Report, which called for a large-scale overhaul of the ECOWAS decision-making process, the new ECOWAS treaty reshaped the institutional set-up of the organization. It included a Community Parliament and an Economic and Social Council among others. Even if the creation of a specific security body was left outside the 1993 treaty, ECOWAS continued its involvement in regional security through ECOMOG. ${ }^{8}$

\footnotetext{
${ }^{7}$ While ECOWAS was not exactly new to security declarations - in 1976 member states signed the Treaty on Non-Recourse to Aggression, in 1978 they signed the Protocol on Nonaggression, and in 1981 ECOWAS released a Protocol on Mutual Assistance on Defense (which was, however, not implemented) - ECOMOG was the first time ECOWAS was engaged in crisis management and had an active role in security issues. The significance of ECOMOG can also be glimpsed by the fact that it later served important roles in the Sierra Leone conflict, GuineaBissau, Liberia and Cote d'Ivoire.

${ }^{8}$ The Mediation and Security Council marking the shift from ad hoc conflict resolution procedures to a more permanent structure was added only in 1997.
} 
ECOWAS' greater de facto scope at the end of the 1980s confronted the organization with the need to adapt its institutional design. This coincided with the view, expressed by the members in the political declaration of 1991 (ECOWAS 1991a) that community building was the best instrument to non-aggression, stabilization and economic recovery. General Yakubu Gowon, Nigeria's former head of state and promoter of ECOWAS, hoped that this transformation would result in increased public visibility for the organization (ECOWAS 1991b). ${ }^{9}$ In this context, the designers of the reform introduced the Community Parliament as an instrument to connect communities of the region.

In considering a new set-up, the Committee drew heavily from the example of the EU, as is explicit throughout the document (Eminent Persons Report 1993). The completion of the European internal market, an exceptional event at the time, added to the Committee's recommendation that the formation of various institutional bodies was desirable. Given the goals that the reform had set out, one can understand this as an attempt to import legitimacy from an established design whose usefulness and appropriateness was taken for granted (Koitzsch 2012). As a result, ECOWAS ended up simply proposing its own community method of decision-making (Bourenane 1997). The proposal of an IPI was both coherent with the regional-building goals of member states and part of an accepted template of a successful and legitimate regional organization. Yet ECOWAS created the Parliament in form only, without necessarily giving much thought to what specific role it should play. Indeed, for a long time after the new treaty came into effect, the Parliament was not functional. Its first meeting was in 2001, eight years after the new treaty was signed.

To back the argument we also examine whether it was not an increase in democratic levels of member states that led to the creation of the IPI. At first glance, the strong democratic rhetoric present in the Eminent Persons Report as well as the 1991 political declaration (ECOWAS 1991a) point at domestic democratic legitimacy pressures playing a role in the creation of the IPI. While the 1991 declaration includes no explicit mention of legitimacy or representativeness at the regional level, it insists on domestic democratic promotion. In addition, the new ECOWAS treaty commits its members to the recognition, protection, and promotion of human rights, the principles of "accountability, economic and social justice and popular participation in development", and Article 4 more specifically pushes states to promote and consolidate a "democratic system of governance in each member state" (ECOWAS 1993).

Despite all the above, the idea that domestic legitimacy pressure arose from domestic democratization is questionable. The share of democracies in ECOWAS only increased from 6 to 31 percent between 1990 and 1992

\footnotetext{
${ }^{9}$ We are grateful to Densua Mumford for sharing this document with us.
} 
and dropped again for the remainder of the decade. These low shares make it implausible for member states to have been committed to raise domestic popular representation at the international level (Koitzsch 2012). Moreover, while democratic transitions occurred in Cape Verde, Niger and Mali, the regional hegemon - Nigeria - was experiencing especially turbulent years under the rule of General Babangida. The only states that had been fullfledged democracies for at least some years before 1993 were Gambia and Cape Verde. Given their size compared to the regional heavyweight, it is unlikely that they could have successfully bargained for regional democracy. It is more plausible that the rhetoric adopted by the delegates was a commonly acceptable script in a scenario of political stabilization than a genuine response to domestic pressure for democratization. The fact that the direct election of parliamentarians, a provision included in the new treaty, has never been implemented is further proof that democratic rhetoric was an empty gesture.

The ECOWAS case shows that the general-purpose orientation of the organization did not immediately produce demand for the establishment of an IPI. It took a major institutional overhaul of the organization, which renewed and reinforced its region-building purpose and open-ended policy mandate, and a conducive international environment, in which the EU had ascended to a global template of regional integration, for regional decisionmakers to accept the creation of the ECOWAS Parliament. By contrast, domestic democratization can be excluded as a relevant driver of parliamentarization. In the absence of strong domestic democracy, institutional mimicry was oriented towards a parliament outside the region, and decoupling was profound.

\subsection{The Non-Establishment of a PIF Parliament}

PIF was established in 1971 as a direct response to Pacific Islanders' emancipation from their former colonial powers and their regional IO (the South Pacific Commission). Over time, PIF became the primary organization in the South Pacific realm, currently comprising 15 member states. As the region's foremost IO, PIF was in the beginning set up as a forum where any subject could be raised (Fry 1981). Regional integration was, however, never explicitly one of its goals and hence the organization cannot be considered a general-purpose one. After 2003, when PIF experienced an institutional crisis, region-building was attempted but ultimately failed. Hence, according to our main hypothesis, it should not come as a surprise that the organization never developed an IPI. Even though most of its members would be considered democracies, PIF attempted to resolve its legitimacy crisis not by means of creating a parliamentary organ, but by giving voice to civil society in the decision-making process, a course of action we would expect from a task-specific organization. The following discussion shows the causal mechanism of our argument about types of IOs at work in this typical negative case. We draw upon original interviews with policymakers and PIF technocrats in Fiji, as well as archival research at the IO's headquarters and secondary literature to show that because PIF practically never was a general-purpose 
organization, it also did not develop an IPI. Concurrently, similar to the ECOWAS case, process-tracing here reveals that the average level of democracy of member states in an IO is not crucial for explaining IPI existence.

One cannot understand the creation of PIF without first mentioning the South Pacific Commission, an IO initially set up by colonial powers with the objective of promoting economic and social development, but precluding any talk of political issues. The limits bigger states placed on this IO prompted Pacific Islanders to discuss the possibility of a new organization wherein they could tackle topics such as decolonialization or nuclear testing (Fry 1981). The first meeting of the newly created PIF took place in 1971 and participating leaders engaged in talks including issues such as trade, shipping, civil aviation, tourism, education, telecommunications, nuclear testing, and regional cooperation more broadly (South Pacific Forum 1971). Following this first gathering, leaders in the region proceeded to establish various affiliated institutions (the South Pacific Bureau for Economic Cooperation or the South Pacific Organizations Coordinating Committee, later renamed the Council of Regional Organizations or CROP) that would help PIF implement its technical programs. First concerned primarily with economic issues, PIF started expanding its reach to issues concerning environmental protection, resource management and even decolonialization. In the 1990s PIF began engaging with security issues directly by signing several cooperation declarations. In particular, the Biketawa Declaration that was signed in 2000 was momentous as it committed IO members to collectively address 'sensitive issues' and later triggered the IO's first on-theground military operation in the wake of unrests in Solomon Islands in 2003 (Peebles 2005).

All of these developments, however, happened in the context of the IO not having an international legal personality. Issues were addressed on an ad hoc basis and region-building was never made explicit in member states' goals. At the first meeting in Wellington in 1971 for example, participating states made clear that "talks were essentially exploratory" and that while they hoped the talks would advance "the spirit of regional cooperation and mutual confidence," the meeting was nevertheless "an ad hoc gathering." (South Pacific Forum 1971) Thus, even though the tasks and scope of PIF gradually expanded from the 1970s to the 2000s, PIF nonetheless remained an organization that did not have a general purpose but that was used by leaders to solve immediate concerns. Hence, attempts at parliamentarization during this period were quickly dismissed by the majority of participating states as an IPI would not have served the specific mandates of PIF. In 1985, when New Zealand put forth a proposal to set up an interparliamentary body, ${ }^{10}$ the discussion was tabled for the next year, in the hope that member

\footnotetext{
'0 New Zealand's proposal most likely came at the behest of Mike Moore, a Member of Parliament in New Zealand at the time, who had written a book in 1982 advocating for a Pacific Parliament. In his book, Moore maintains that establishing a regional parliament would be beneficial both for PIF as well as the South Pacific Commission, as this would allow them to "rationalize their functions and roles" and help the two IOs become more efficient by dealing with details and administrative issues (Moore 1982: 41-42). In a sense, Moore did not want a parliament attached to PIF, but a regional parliament that would take over the functions of both PIF and the South Pacific Commission, in the hope that this would lead to further regional integration.
} 
states would then have a more informed conversation about this possibility (South Pacific Forum 1985). In 1986, however, the discussion was never picked up again, attesting to member states' disinterest. Similarly, in 1995 , when Vanuatu raised the issue of setting up an assembly that would better represent the views of Pacific Island populations, other states did not receive this idea well (South Pacific Forum 1995). Member states voiced their concerns about who the authorities representing communities at such meetings would be and again dismissed the vague proposal. In other words, some smaller island states were reluctant to cede more authority to another regional body. Finally, the reluctance of PIF member states to set up an affiliated IPI is also visible with regard to how the Forum Presiding Officers Conference was handled. The latter had been an institution attached to PIF that was established in 2000 and where speakers and clerks of Pacific parliaments could meet. The institution, however, never evolved into an IPI and never received permanent funding. As a result, in 2007 it merged with the Pacific Parliamentary Assembly on Population and Development, thereby creating a new institution unaffiliated with PIF.

After PIF's intervention in the Solomon Islands to stop ethnic violence, member states saw an opening to re-think the IO's role, functions and secretariat. On the one hand, member states were unhappy with the practical effects PIF's policies and declarations had. On the other hand, with the advent of a global drive towards regionalism and an increased importance of regional trading blocs in the 1990s, some member states felt it was important to push for region-building more explicitly. In particular, Australia and New Zealand voiced strong opinions about this new course of action that would allegedly make small island states more economically viable. ${ }^{11}$ Member states therefore tasked an Eminent Persons' Group (EPG) with the redesign of PIF. After extensive consultations with member state leaders, the Eminent Persons' Group delivered a report in 2004 emphasizing regional cooperation and a more stable and official personality for the IO, as well as closer contact between PIF and local populations, among other issues (Pacific Islands Forum 2004). It was therefore understood that for region-building to happen, PIF had to increase its legitimacy in the eyes of Pacific Islanders.

The plan that was ultimately adopted by PIF leaders in 2005, ostensibly in line with the EPG recommendations, nonetheless failed with respect to region-building. PIF was formally established as an international organization with the purpose of strengthening regional cooperation and integration (Pacific Islands Forum 2005). The strengthening of regional cooperation, however, was understood as only "further[ing] Forum members' shared goals of economic growth, sustainable development, good governance, and security" (Pacific Islands Forum 2005). Member states differed with respect to how much region-building the organization should do. While Australia and New Zealand wanted a more extensive organization, small Pacific Island states were unwilling to engage in region-building through a supranational organization that ultimately seemed to be governed

\footnotetext{
"Personal interview with expert on Pacific region, 7 February 2017 (b).
} 
by 'outside states'. With the exception of Australia and New Zealand, PIF members are all young states wary of ceding newly-gained powers and thus wary of too much region-building. The animosity smaller states in PIF have towards Australian and New Zealand proposed region-building projects was visible before the re-organization of the IO in 2001, when a Fijian leader and original founder of PIF expressed his dissatisfaction by saying, "[greater powers] have sought to impose their solutions in an insensitive way, when left to ourselves we could work things out in what we have called the Pacific Way" (Mara 2001). The issue came to the fore again in 2004 when the Pacific Plan to be adopted in accordance with the EPG report was labeled as a neoliberal endeavor inspired and influenced by the two bigger neighbors (Fry and Tarte 2015). To this day, the unease small island states have with respect to increased interference from outside powers continues - PIF technocrats are for instance trying to move towards a system in which big donors are only involved in budget support, and not policy design and implementation, ${ }^{12}$ and most recently, small islands states also established a rival organization, the Pacific Islands Development Forum, in which Australia and New Zealand do not participate (Pareti 2013).

Because PIF never transformed into a general-purpose organization with an open-ended contract geared towards region-building and the formation of a political community, nor did member state leaders seriously entertain this idea, the IO did not establish an IPI. In fact, while the EPG report emphasized engagement with local populations, the 2005 Pacific Plan according to which PIF was formally established focused on ensuring economic integration without concern for institutional legitimacy. As a result, the Plan was heavily criticized and became a 'living document' that was ultimately redrafted in 2012. A New Framework for Pacific Regionalism was adopted in 2014 explicitly mentioning that regional projects would be decided on an ad-hoc basis, by means of a new independent sub-committee tasked with assembling and assessing annual proposals from state and non-state actors (Slatter 2015). Through the new framework, civil society got a seat at the table, but only nominally. As various experts, civil society spokespeople and even PIF secretariat representatives made clear in interviews, the new decision-making process is problematic as it is not truly inclusive. ${ }^{13}$ Civil society proposals became hijacked and changed at leader's meetings and various bottlenecks exist so that member states effectively retain the power to decide on PIF policies.

Given small island states' opposition to region-building projects and thus towards reforming PIF into a true general-purpose organization, democratic procedural legitimacy was secondary in importance in the newly revamped IO. Notwithstanding the fact that a majority of PIF member states' are democracies (their average polity

\footnotetext{
12 Personal interview with individual affiliated with PIF, 7 February 2017.

" Personal interview with expert on Pacific region, 7 February 2017 (b), personal interview with individual affiliated with PIF, 8 February 2017, personal interview with individual affiliated with civil society in the Pacific, 15 February 2017.
} 
score fluctuates somewhat given occasional coups, but rarely drops below 6 and sometimes is as high as 9.6), without the IO being a general-purpose organization, domestic demand for a representative institution was almost non-existent. A lengthy discussion concerning civil society involvement took place after 2004, but an IPI was never seriously taken into consideration in an organization that did not have an open-ended territorial community as its goal. An international parliament was not perceived as suitable for increasing the IOs legitimacy. Finally, the comparison of ECOWAS and PIF is instructive because both IOs have developed a large policy scope over time. Yet without a regional community-building purpose, this scope did not translate into broad demand for or acceptance of an IPI in the PIF case. For the same reason, the EU did not serve as a model of regional institutional design in the reform of the PIF.

\subsection{Conclusions}

While IPIs have become a widespread feature of IO institutional design, mainstream theories of delegation do not convincingly account for their emergence. We explain the creation of IPIs as an attempt of member states to provide IOs with democratic legitimacy. They exploit the analogy of IPIs with national parliaments, the quintessential democratic institution, to create the appearance of international democracy, without, however, vesting them with tangible powers. Specifically, IPIs are plausible responses to the legitimation needs that policymakers encounter in general-purpose organizations.

We examine the consistency of the evidence with our argument in a nested, quantitative and qualitative analysis. In this context, we also contrast our institutional fit expectation with two plausible alternatives focusing on the delegation of authority to IOs and member state democracy. Analyzing a sample of 73 IOs with standing in international politics, we observe a substantially highly important relationship between the general-purpose character of IOs and the emergence and persistence of IPIs. This relationship holds independently of how democratic IO member states are. Moreover, the delegation of authority to IOs, in contrast to their organizational purpose, is not consistently associated to IPIs. ${ }^{14}$ Our case studies of ECOWAS and PIF, which were specifically selected to disentangle the impact of organizational purpose and domestic democracy, add further plausibility to our argument. The predominantly undemocratic ECOWAS established an IPI in the context of an organizational transformation reinforcing its general-purpose orientation. By contrast, the predominantly democratic PIF did not establish an IPI because member states did not want to further engage in region-building and did not conceive of the purpose of their IO in these terms.

\footnotetext{
${ }^{14}$ Similarly, Anderson et al. (2019) find that the procedural quality of international authority, rather than its strength, affects legitimacy perceptions.
} 
The strategic perspective on the democratic legitimation of international institutions that we adopt in this paper raises several follow-up questions. First, what are the prospects for an international parliamentarization process driven by the strategic reliance of member states on the institutional fit between IPIs and general-purpose IOs? Second, how likely is it that weak IPIs become more powerful over time despite the reluctance of member state governments to endow them with significant competences from the start? Third, how effective is the creation of IPIs in affecting the legitimacy beliefs of citizens?

Our analysis suggests that the parliamentarization of IOs does not follow a linear trajectory but rather waxes and wanes with "regionalism", understood as a "primarily state-led process of building and sustaining formal regional institutions and organizations" (Börzel and Risse 2016: 7) with an open-ended policy agenda and community-formation purpose. As FIGURE 1 shows, the share of IOs with IPIs first peaked during the post-World War II rise of regionalism, decreased with the crisis in regionalism (Haas 1976) and increased again strongly during the post-Cold War renaissance of regionalism. In line with our finding as to the importance of domestic democracy, the rise of IPIs also matches the waves of democratization in the post-World War II international system. As our ECOWAS case study and the general relevance of the African continent for the second phase of IO parliamentarization show, however, IPI creation has become partially independent of member state democracy. Rather, the EU has served as model for regional institution-building in general and IPI creation in particular (Risse 2016; Lenz and Burylkov 2017). Yet, the end of the post-Cold War democratization wave, the crisis of European integration, and the challenges to multilateral international institutions more broadly, diminish exogenous incentives for further IO parliamentarization. Indeed, FIGURE 1 suggests that IPI creation and IO parliamentarization have stagnated in the recent period.

The weakening of exogenous drivers for the creation of new IPIs raises the question of whether existing parliamentary bodies might achieve endogenous increases of their authority over time. The prototypical case is the EP, which started as a largely powerless IPI in 1952, took 35 years to acquire (weak) legislative powers in 1987, but today boasts co-decision powers on EU laws, the EU budget and the appointment of the European Commission (Rittberger 2005). Perhaps, as an optimistic interpretation might run, many IPIs are too young and have had too few opportunities to secure greater competences (Falk and Strauss 2001). Moreover, there are examples of the EP exploiting the EU's open-ended and generic decision-making procedures to extract additional competences from national governments (Hix 2002). The emergence of IPIs in general-purpose organizations with open-ended procedures suggests that they could pursue similar empowerment strategies. Yet, the EP acquired many of its competences through the entrepreneurship of federalist European and national parliamentarians, often challenging the preferences of governments (Rittberger 2005). The spread of IPIs in world regions in which federal ideology 
and parliamentarians' autonomy from executives is likely to be weaker warrants skepticism as to the possibility that IPIs will extract significant authority from reluctant governments. Indeed, empirically, only 20 percent of the IPIs in our data have ever seen their powers improved - and then typically weakly and incrementally.

Finally, the question of whether the strategic legitimation of IOs by shallow parliamentarization actually improves the perceived democratic legitimacy of IOs among national and international audiences requires future research. By creating IPIs, governments dilute the most obvious institutional evidence of executive bias and the exclusion of society from their IOs. However, without significant competences, parliamentary bodies are unlikely to exercise strong accountability, secure representative IO policies, or achieve significant public visibility. Whether the appearance of parliamentarization alone is enough to enhance IO legitimacy thus remains open to question. Indeed, it could be problematic if shallow parliamentarization proved enough to change national and international legitimacy beliefs. Our conclusions should remind scholars and practitioners that the existence of IPIs could lend unwarranted legitimacy to organizations and actors that fail to meet democratic standards in practice.

\subsection{References}

Abbot, R. L. (1969). The Caribbean Free Trade Association. Retrieved from University of Miami InterAmerican Law Review: http://repository.law.miami.edu/cgi/viewcontent.cgi?article=2433\&context=umialr

Anderson, B., Bernauer, T., \& Kachi, A. (2019). Does International Pooling of Authority Affect the Perceived Legitimacy of Global Governance? Review of International Organizations, this issue.

Bach, D. (1983). The Politics of West African Economic Co-operation: CEAO and ECOWAS. The Journal of Modern African Studies, 21(4), 605-623.

Berry, W. D., DeMeritt, J. H., \& Esarey, J. (2010). Testing for Interaction in Binary Logit and Probit Models: Is a Product Term Essential? American Journal of Political Science, 54(1), 248-266.

Börzel, T.A., \& Risse, T. (2016). Introduction. In T.A. Börzel and T. Risse, The Oxford Handbook of Comparative Regionalism (pp. 3-15). Oxford: Oxford University Press.

Buchanan, A., \& Keohane, R. (2006). The Legitimacy of Global Governance Institutions. Ethics and International Affairs 20(4), 405-437.

Chayes, A., \& Handler Chayes, A. (1998). The New Sovereignty: Compliance with International Regulatory Agreements. Cambridge: Harvard University Press.

Cheibub, J. A., Gandhi, J., \& Vreeland, J. R. (2010). Democracy and Dictatorship Revisited. Public Choice, 143(1-2), 67-101. 
Cofelice, A. (2012). Interregional Parliamentary Assemblies: A New Layer in the Multi-level Global Governance System. In L. Bekemans, Intercultural dialogue and Multi-level Governance. A Human Rights based Approach (pp. 277-292). Brussels: P.I.E. Peter Lang.

Coppedge, M., Gerring J., Lindberg S., Skaaning, S., Teorell, J., Altman, D., Andersson, F., Bernhard, M., Fish, S., Glynn, A., Hicken, A., Henrik Knutsen, C., McMann, K., Mechkova V., Miri F., Paxton, P., Pemstein, D., Sigman, R., Staton, J., \& Zimmerman, B. (2016). “V-Dem Codebook v6.” Varieties of Democracy (V-Dem) Project.

Costa, O., Dri, C., \& Stavridis, S. (2013). Parliamentary Dimensions of Regionalization and Globalization. New York: Palgrave Macmillan.

Delegation under Anarchy: States, International Organizations, and Principal-Agent Theory. (2006). In D. G. Hawkins, D. A. Lake, D. L. Nielson, \& M. J. Tierney, Delegation and Agency in International Organizations (pp. 3-38). Cambridge: Cambridge University Press.

Dellmuth, L., \& Tallberg, J. (2015) The social legitimacy of international organisations: Interest representation, institutional performance, and confidence extrapolation in the United Nations. Review of International Studies, 41(3), 451-475.

Dennis, P., \& Leanne, B. (2004). The ECOWAS: From Regional Economic Organization to Regional Peacekeeper. In F. Laursen, Comparative Regional Integration: Theoretical Perspectives (pp. 229-249). Aldershot: Ashgate.

ECOWAS. (1979). Treaty of the Economic Community of West African States (ECOWAS). Retrieved September 22, 2017, from International Democracy Watch:

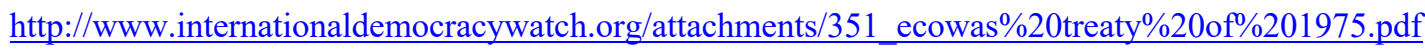

ECOWAS. (1991a). Declaration A/DCL.1/7/91 of Political Principles of the Economic Community of West African States 1991 Jul 06

ECOWAS. (1991b). Opening Statement by General Yakubu Gowon (RTD) Chairman of the Committee of ECOWAS. (1992). Review of the ECOWAS Treaty: Final Report by the Committee of Eminent Persons.

ECOWAS. (1993). Economic Community of West African Affairs - Revised Treaty. Retrieved September 22, 2017, from ECOWAS: http:/www.ecowas.int/wp-content/uploads/2015/01/Revised-treaty.pdf

Eminent Persons for the Review of the ECOWAS Treaty Delivered at the Opening Session of Inaugural Meeting of the Committee. pp. 6-7

Falk, R., \& Strauss, A. (2001). Toward Global Parliament. Foreign Affairs, 80, 212-217.

Føllesdal, A., \& Hix, S. (2006). Why There is a Democratic Deficit in the EU: A Response to Majone and Moravcsik. Journal of Common Market Studies, 44(3), 533-562.

Franck, T. (1988). Legitimacy in the International System. American Journal of International Law 82(4), $705-$ 759 . 
Fry, G. (1981). Regionalism and international politics in the South Pacific. Pacific Affairs, 54(3), 455-484.

Fry, G., \& Tarte, S. (2015). The 'new pacific diplomacy':An introduction. In G. Fry \& S. Tarte, The New Pacific Diplomacy (pp. 3-20). Canberra, Australia: ANU Press.

Grigorescu, A. (2010). The Spread of Democratic Oversight Mechanisms across Intergovernmental Organizations. International Studies Quarterly, 54(3), 871-886.

Haas, E.B. (1976). Turbulent Fields and Regional Integration Theory. International Organization, 30(2), 173212.

Hix, S. (2002). Constitutional Agenda-Setting Through Discretion in Rule Interpretation: Why the European Parliament Won at Amsterdam. British Journal of Political Science 32(2), 259-280.

Hooghe, L., \& Marks, G. (2003). Unravelling the Central State, but How? Types of Multi-Level Governance. American Political Science Review, 97(2), 233-243.

Hooghe, L., \& Marks, G. (2015). Delegation and Pooling in International Organizations. The Review of International Organizations, 10(3), 305-328.

Hooghe, L., \& Marks, G. (2016). Community, Scale, and Regional Governance: A Postfunctionalist Theory of Governance, Volume II. Oxford: Oxford University Press.

Hooghe, L., Marks, G., Lenz, T., Bezuijen, J., Ceka, B., \& Derderyan, S. (2017). Measuring International Authority: A Postfunctionalist Theory of Government (Vol. IV). Oxford: Oxford University Press.

Hurd, I. (1999). Legitimacy and Authority in International Politics. International Organization 53(2), 379-408.

Keohane, R. (1984). After Hegemony. Cooperation and Discord in the World Political Economy. Princeton: Princeton University Press.

Keohane, R. O., Macedo, S., \& Moravcsik, A. (2009). Democracy-Enhancing Multilateralism. International Organization, 63(1), 1-31.

Kissling, C. (2014). The Legal and Political Status of International Parliamentary Institutions. In L. Levi, G. Finizio, \& N. Vallinoto, The Democratization of International Institutions: First International Democracy Report (pp. 25-53). New York: Routledge.

Koitzsch, C. (2012). Institutional Similarities between Regional Organizations: An Analysis of ECOWAS and the Arab League. In T. A. Börzel, L. Goltermann, \& K. Striebinger, Roads to Regionalism: Genesis, Design, and Effects of Regional Organizations (pp. 117-137). Burlington: Routledge.

Lenz, T. (2013). External Influences on Regionalism: Studying EU Diffusion and its Limits. Retrieved September 22, 2017, from E-International Relations: http://www.e-ir.info/2013/07/17/externalinfluences-on-regionalism-studying-eu-diffusion-and-its-limits/

Lenz, T., \& Burylkov, A. (2017). Institutional Pioneers in World Politics. Regional Institution Building and the Influence of the European Union. European Journal of International Relations, 23(3), 654-680. 
Lenz, T., Bezuijen, J., Hooge, L., \& Marks, G. (2015). Patterns of International Authority: Task Specific vs General Purpose. Politische Vierteljghresschrift, 49, 131-156.

Lenz, T., \& Viola, L. (2017). Legitimacy and institutional change in international organisations: a cognitive approach. Review of International Studies 43(5), 939-961.

Lieberman, E. (2005). Nested Analysis as a Mixed-Method Strategy for Comparative Research. American Political Science Review, 99(3), 435-452.

Mair, S., \& Peters-Berries, C. (2001). Regionale Integration und Kooperation in Afrika südlich der Sahara EAC, ECOWAS und SADC im Vergleich. Forschungsberichte des Bundesministeriums für Wirtschaftliche Zusammenarbeit und Entwicklung. Bonn: Weltforum-Verlag.

Majone, G. (2001). Two Logics of Delegation: Agency and Fiduciary Relations in EU Governance. European Union Politics, 2(1), 103-122.

Majone, G. (2002). The European Commission: The Limits of Centralization and the Perils of Parliamentarization. Governance, 15(3), 375-392.

Mara, R. (2001). Keynote address on the occasion of the 30 anniversary of the South Pacific Forum of Leaders, Yaren Nauru, 16 August.

Marc, A., Verjee, N., \& Mogaka, S. (2015). The Important Role of ECOWAS in Developing West Africa's Security Architecture. In A. Marc, N. Verjee, \& S. Mogaka, The Challenge of Stability and Security in West Africa (p. 158). Washington, D.C.: World Bank Publications.

Meyer, J., \& Rowan, B. (1977). Institutionalized organizations: formal structure as myth and ceremony. American Journal of Sociology 83(2), 340-363.

Moore, M. (1982). A Pacific Parliament. Wellington, NZ: Asia Pacific Books.

Naceur, B. (1997). Theoretical and Strategic Approaches. In R. Lavergne, Regional Integration and Cooperation in West Africa: A Multidimensional Perspective (pp. 49-63). Trenton: Africa World Press.

Nielson, D., \& Tierney, M. (2003). Delegation to International Organizations: Agency Theory and World Bank Environmental Reform. International Organization, 57(2), 241-276. doi:10.1017/S0020818303572010

Ojo, O. (1980). Nigeria and the Formation of ECOWAS. International Organization, 36(1), 571-604.

Pacific Islands Forum. (2004). The Eminent Persons' Group Review of the Pacific Islands Forum, April 2004. Available at: http://www.iri.edu.ar/publicaciones iri/anuario/CD\%20Anuario\%202005/Asia/47pacific\%20island\%20forum-eminent\%20persons\%20report\%2004.pdf

Pareti, S. (2013). Fiji pushes for alternative to Pacific Islands Forum. ABC News Online, 6 August.

Peebles, D. (2005). Pacific Regional Order. Canberra, Australia: ANU E Press and Asia Pacific Press.

Risse, T. (2016). The Diffusion of Regionalism. In T.A. Börzel and T. Risse, The Oxford Handbook of Comparative Regionalism (pp. 87-108). Oxford: Oxford University Press. 
Rittberger, B. (2005) Building Europe's Parliament. Democratic Representation Beyond the Nation-State. Oxford: Oxford University Press.

Rittberger, B. (2006). No Integration without Representation! European Integration, Democracy, and Two Forgotten Communities. Journal of European Public Policy, 8, 1211-1229.

Rittberger, B., \& Schroeder, P. (2016). The Legitimacy of Regional Institutions. In T. A. Börzel, \& T. Risse, The Oxford Handbook of Comparative Regionalism. Oxford: Oxford University Press.

Seawright, J., \& Gerring, J. (2008). Case selection techniques in case study research. Political Research Quarterly, 61(2), 294-308.

Slatter, C. (2015). The new framework for pacific regionalism: Old kava in a new tanoa? In G. Fry \& S. Tarte, The New Pacific Diplomacy (pp. 49-63). Canberra, Australia: ANU Press.

South Pacific Forum. (1971). Joint Final Communiqué, Pacific Islands Forum Secretariat. Wellington 5-7

August. Available at: http://www.forumsec.org/pages.cfm/about- us/secretariat/walk-down-memorylane/South Pacific Forum. (1985). South Pacific Bureau for Economic Cooperation Committee Meeting, Rarotonga 30 July - 1 August. Available from the Pacific Islands Forum Secretariat archives.

South Pacific Forum. (1995). Forum Officials Committee - Pre-Forum Session, Madang, 10-12 September. Available from the Pacific Islands Forum Secretariat archives.

Tallberg, J. and Zürn, M. (2019). The Legitimacy and Legitimation of International Organizations: Introduction and Framework. Review of International Organizations, this issue.

Tallberg, J., Sommerer, T., \& Squatrito, T. (2016). Democratic Memberships in International Organizations: Sources of Institutional Design. Review of International Organizations, 11(1), 59-87.

Tallberg, J., Sommerer, T., Squatrito, T., \& Jönsson, C. (2013). The Opening Up of International Relations. Cambridge: Cambridge University Press.

Tallberg, J., Sommerer, T., Squatrito, T., \& Jönsson, C. (2014). Explaining the Transnational Design of International Organizations. International Organization, 68(4), 741-774.

Thomas, R. (2016). The Diffusion of Regionalism. In T. A. Börzel, \& T. Risse, The Oxford Handbook of Comparative Regionalism. Oxford: Oxford University Press.

Van Nieuwkerk, A. (2011). The Regional Roots of the African Peace and Security Architecture: Exploring Centre-Periphery Relations. South African Journal of International Affairs, 18(2), 169-89.

Wucherpfenning, J., Hunziker, P., \& Cederman, L.-E. (2016). Who Inherits the State? Colonial Rule and Postcolonial Conflict. American Journal of Political Science, 60(4), 882-898. 